\title{
ANALISIS PERBEDAAN FITTING FACTOR ANTARA POLA SONNY DAN POLA PRAKTIS PADA JAS WANITA
}

\author{
Irmayanti \\ Fakultas Teknik Universitas Negeri Makassar \\ E-mail: irmayanti@unm.ac.id
}

\begin{abstract}
Abstrak
Busana memiliki peranan penting bagi manusia dalam kehidupan sehari-hari. Busana bukan hanya sekedar mengenakan pakaian, akan tetapi pilihan busana yang tepat dapat menjadikan penampilan seseorang menjadi sangat mengesankan. Baik atau tidaknya busana yang dikenakan dibadan seseorang (kup) sangat dipengaruhi oleh kebenaran pola itu sendiri. Pola dasar sistem "Sonny" merupakan pola dasar yang biasa digunakan dalam pembuatan jas wanita, sedangkan pola dasar praktis merupakan pola dasar yang telah dimodifikasi dari penggabungan beberapa pola dasar yang telah ada. Penelitian ini bertujuan untuk menguji signifikansi perbedaan fitting factor hasil jadi pembuatan jas wanita yang menggunakan pola sistem sonny dan praktis. Metode penelitian yang digunakan secara kuantitatif, data dikumpulkan melalui observasi dan dianalisis menggunakan $t$ test. Hasil penelitian menunjukkan terdapat perbedaan yang signifikan pada fitting factor hasil jadi pembuatan jas wanita antara yang menggunakan pola sistem Sonny dengan pola sistem Praktis
\end{abstract}

Kata kunci : Fitting factor, Pola Sonny, Pola Praktis

\section{Abstract}

Clothing has an important role for humans in everyday life. Clothing is not just wearing clothes, but the right choice of clothing can make a person look very impressive. Whether or not the clothing worn by a person's body (coup) is strongly influenced by the truth of the pattern itself. The basic pattern of the "Sonny" system is an archetype commonly used in the manufacture of women's suits, whereas the practical archetype is an archetype that has been modified from the incorporation of some existing archetype. This study aims to test the significance of differences in fitting factor resulting in the manufacture of suits women using sonny and practical system pattern. The research method used quantitatively, data collected through observation and analyzed using t test. The results showed that there was a significant difference in the fitting factor of the finished product of the coat of women between the use of Sonny system pattern with Practical system pattern.

Keywords: Fitting factor, Sonny Pattern, Practical Pattern

\section{PENDAHULUAN}

Busana merupakan kebutuhan yang mutlak bagi manusia, karena busana memiliki peranan yang penting dalam kehidupan sehari-hari. Menurut Eka (2011: 3), busana sangat berpengaruh pada rohani, jasmani, usia dan bentuk tubuh seseorang. Busana bukan hanya sekedar mengenakan pakaian, akan tetapi pilihan busana yang tepat sesuai untuk kesempatan dan sesuai pula dengan kepribadian pemakainya, dapat menjadikan penampilan seseorang baik wanita maupun pria menjadi sangat mengesankan.

Perkembangan zaman yang semakin maju juga sangat berdampak pada perkembangan dunia mode dan busana. Para designer juga ikut meningkatkan kreativitasnya dan keahliannya dalam merancang dan menciptakan karya busana. Hal tersebut pula berdampak bagi mahasiswa Tata Busana Jurusan Pendidikan Kesejahteraan Keluarga Fakultas Teknik 
Universitas Negeri Makassar agar semakin meningkatkan kompetensi dalam menghasilkan karya seni/produk busana yang bermutu dan berkualitas sehingga lulusannya mampu bersaing di masyarakat baik sebagai akademisi maupun sebagai praktisi.

Matakuliah Tailoring merupakan kompetensi keahlian Tata Busana tingkat mahir yang harus dimiliki oleh setiap mahasiswa tata busana. Oleh karena itu, mahasiswa dituntut untuk mampu mengetahui, memahami dan menerapkan teknik tailoring pada pembuatan jas wanita. Adapun kompetensi yang diharapkan setelah mengikuti Matakuliah Tailoring yaitu mahasiswa mampu (1) mengidentifikasi dan mendeskripsikan teori tailoring meliputi pengertian dan klasifikasi tailoring, hakikat mantelpak dan sejarah jas; (2) membuat pola jas (pattern making) sesuai desain/model; (3) mengesplorasi teknik menggunting (cutting), menjahit jas dan mengepres jas dengan kualitas yang baik. Penyelesaian busana dengan teknik tailoring membutuhkan ketelitian dan kecermatan sehingga mahasiswa Tata Busana dituntut memiliki kemahiran, ketelitian dan kesabaran dalam belajar. Hasil belajar pada matakuliah Tailoring berkaitan dengan penilaian kerja mahasiswa dalam pembuatan pola (pattern making), menjahit (sewing), pengepasan (fitting), penyelesaian (finising) dan total keseluruhan (total look) produk, serta kecepatan dan ketepatan waktu unjuk kerja dalam penyelesaian tugas.

Akan tetapi timbul satu masalah yang terjadi dalam kegiatan belajar pembuatan jas wanita pada matakuliah Tailoring. Berdasarkan observasi dan pengalaman yang diperoleh dilapangan, ternyata pencapaian kompetensi mahasiswa yang diharapkan pada matakuliah Tailoring tidak dapat tercapai secara maksimal karena sebagian besar mahasiswa tidak dapat menyelesaikan tugas pembuatan jas wanita tepat pada waktunya. Pada umumnya hambatan dan kesulitan yang ditemui mahasiswa terjadi pada saat pembuatan pola dan pecah pola jas. Selain itu, karena adanya hambatan dan kesulitan yang ditemui mahasiswa dalam pembuatan pola, menyebabkan hasil akhir dari produk busananya kurang memuaskan. Diantaranya yaitu: (1) titik pas / fitting factor yang tidak sesuai dibadan (2) pemakaian yang kurang nyaman ketika dikenakan, (3) pengepresan yang kurang rapi, (4) letak dan bentuk saku serta kerah yang kurang tepat.

Busana yang baik adalah busana yang nyaman ketika dikenakan, tidak longgar dan tidak sempit. Busana akan terlihat sempurna bila mode pakaian yang dijadikan acuan sesuai dengan tubuh si pemakai. Menurut Sulistio, untuk mendapatkan hasil busana yang baik, tidaklah mudah, sebab memerlukan latihan, keterampilan serta pengalaman dalam lingkup perbusanaan yang salah satunya yaitu dengan cara mempelajari penerapan pola. Selanjutnya Riyanto (203: 266) mengemukakan bahwa keterampilan pembuatan busana termasuk di dalamnya mulai dari belajar mengukur, mengenal tanda-tanda pola, membuat pola dasar dan mengubah pola sesuai model, merancang bahan dan harga, memotong dan menjahit.

Ernawati, dkk (2008:245) mengemukakan bahwa pola sangat penting artinya dalam membuat busana. Baik atau tidaknya busana yang dikenakan dibadan seseorang (kup) sangat dipengaruhi oleh kebenaran pola itu sendiri. Selain itu, Andriyanti (2010) mengemukakan bahwa masalah yang sering muncul dalam pemakaian busana adalah kurang serasinya antara busana dengan si pemakai yang disebabkan oleh (1) kurang tepatnya desain dengan bentuk jadi busana, proporsi tubuh pemakai, jatuhnya busana pada tubuh atau badan pemakai kurang tepat, 
sehingga mempengaruhi kenyamanan pemakai.

Beberapa hal yang menyebabkan titik pas (fitting factor) dan kenyamanan pemakaian suatu busana menjadi kurang diantara yaitu: (1) letak garis pinggang yang tidak tepat, (2) penempatan dan pemindahan kupnat yang tidak sesuai, (3) terjadinya kerut dan gelombang. Apabila hal tersebut terjadi, maka dapat mengakibatkan kurang berkualitasnya suatu busana. Suatu busana dapat dikatakan berkualitas jika busana tersebut enak dipakai, indah dipandang dan bernilai tinggi yang pada akhirnya akan tercipta suatu kepuasan bagi sipemakai. Sebaik-baiknya desain suatu busana, jika dibuat berdasarkan pola yang tidak benar dan garis-garis pola yang tidak luwes seperti lekukan kerung lengan, lingkar leher, maka busana tersebut tidak akan nyaman dipakai.

Berdasarkan pemaparan di atas, maka jelaslah bahwa dalam pembuatan busana sangat diperlukan suatu pola yang tepat, karena dengan adanya pola yang tepat akan mempermudah mahasiswa untuk mempraktekkan kegiatan pembuatan jas wanita secara tepat dan benar. Dengan demikian, maka akan dilakukan uji coba pembuatan jas wanita dengan menggunakan pola dasar sistem Sonny dan Pola sistem praktis sehingga dapat diketahui perbedaan hasil jadi jas wanita diketahui berdasarkan fitting factor dan tingkat kenyamanan dari kedua pola tersebut.

\section{Fitting Factor Jas Wanita}

Kenyamanan dalam berbusana dapat dilihat pada dua kriteria, yaitu ketepatan ukuran dan ketepatan titik-titik pas pada tubuh (fitting factor) (Rachmania, dkk: 2012). Fitting factor merupakan suatu lokasi atau titik pada pakaian yang menentukan sesuai atau tidaknya sistem pola tertentu, untuk bentuk tubuh yang mempergunakannya (Prahastuti, 2012: 25). Titik-titik pas pola dasar busana meliputi (1) kerung leher, (2) kerung lengan, (3) letak bahu, (4) kedudukan kup, (5) lingkar badan, (6) lingkar pinggang dan (7) bagian belakang atau punggung. Dalam pemakaian busana, seringkali ditemukan ketiksesuaian busana dengan pemakainya yang disebabkan kurang tepatnya desain dengan bentuk jadi busana, proporsi tubuh pemakai maupun jatuhnya busana pada tubuh atau badan pemakai sehingga dapat mempengaruhi kenyamanan bagi yang memakai busana tersebut.

Masalah yang biasanya terjadi misalnya pada kupnat yang tidak sesuai pada posisi yang sebenarnya, lingkar kerung lengan yang sempit, garis bahu posisinya kurang tepat maupun garis lingkar pinggang yang terlalu turun atau terlalu tinggi. Pengujian ketepatan titik pas / fitting factor pada penggunaan pola dasar tertentu dapat dilakukan pada saat proses pengepasan (fitting). Pengepasan merupakan salah satu bagian dalam proses dalam pembuatan busana, dimana model memakai busana yang telah dijahit untuk mengetahui cocok atau tidaknya pola busana terhadap bentuk tubuh seseorang. Proses fitting juga biasa terbagi atas dua tahapan, yaitu fitting pertama untuk melihat titip pas pola pada tubuh model, dan fitting kedua untuk melihat titik pas busana yang telah dijahit menggunakan pola yang telah digunakan.

Berdasarkan uraian di atas, maka dapat disimpulkan bahwa titik pas pada tubuh (fitting factor) merupakan salah satu hal penting yang harus diperhatikan dalam pembuatan busana, karena dengan adanya ketepatan letak atau posisi suatu bagian busana akan mempengaruhi tingkat kenyamanan dalam berbusana.

Menurut Nusi (2002) jas wanita diawali dengan sejarah terbentuknya jas untuk perempuan yang asal mulanya adalah justeaucorps yang dikenakan laki-laki Eropa di abad XVII. 
Selanjutnya berbagai rekayasa dan inovasi membawa jas tersebut ke masa modern sehingga patut dan pantas dikenakan oleh perempuan dalam berbagai desain tailored suits. Lebih lanjut, Nusi (2002) menjelaskan bahwa jas berasal dari istilah asing yang disebut blazer, Colbert, coat, jacket dan jaquette.

Maeliah (2010:1) mengemukakan definisi jas yaitu merupakan busana dengan model kerah yang mempunyai kelepak atau rever, berlengan panjang dengan jahitan pada bagian depan dan belakang (lengan jas), dikenakan dengan pantalon yang pada umumnya terbuat dari kain yang sama terutama busana kesempatan pesta atau acara resmi dan kadang berbeda kain antara pantaloon dan jas terutama untuk pemakaian busana kerja atau acara lain, seperti acara reuni atau sering dipakai para artis sebagai pelengkap busana.

Jas untuk wanita umumnya digunakan sebagai atasan yang dipadankan dengan bawahan rok atau celana. Padanan ini dikenal dengan sistem mantelpak atau broekpak. Namun jas juga dapat dipadankan dengan gaun terusan. Adapun macam-macam jas antara lain: (1) jas sport kancing satu; (2) jas sport kancing dua; (3) jas sport kancing tiga; (4) jas dubelry kancing satu; (5) jas dubelry kancing dua; (6) jas diner (tuxedo); (7) Vest Maeliah (2010:2). Menurut Safitri (2015), pembuatan jas cukup rumit karena memerlukan waktu dalam pengerjaannya, ketepatan ukuran, kenyamanan, kerapihan yang tinggi, tertib kerja yang baik dan benar. Nusi (2002:24) mengemukakan beberapa teknik pembuatan jas, antara lain: (1) pembuatan pola jas, (2) merancang bahan dan harga, (3) menggunting, dan (4) menjahit.

\section{Sistem Pembuatan Pola Busana}

Menurut Muliawan (1990:2), pattern atau pola dalam bidang jahit menjahit adalah potongan kain atau kertas yang dipakai sebagai contoh untuk membuat baju, ketika bahan akan digunting. Selanjutnya Tamimi (1982) dalam Ernawati, dkk (2008:245) mengemukakan pola ciplakan bentuk badan yang biasa dibuat dari kertas, yang nanti dipakai sebagai contoh untuk menggunting pakaian seseorang, ciplakan bentuk badan ini disebut pola dasar. Berdasarkan beberapa definisi tentang pola, maka dapat disimpulkan bahwa membuat pola merupakan kegiatan membuat ciplakan bentuk badan sesuai dengan ukuran tubuh pemakai yang kemudian dipakai sebagai contoh membuat pakaian.

Pola busana dapat dibedakan menjadi beberapa macam diantaranya yaitu: (1) pola konstruksi, (2) pola standar, (3) pola teknik drapping. Pola konstruksi adalah pola dasar yang dibuat berdasarkan ukuran badan seseorang dan digambar dengan perhitungan secara matematika sesuai dengan sistem pola konstruksi masisng-masing. Menurut Rachmania, dkk (2012:38), membuat pola konstruksi terdapat dua teknik dasar yaitu teknik konstruksi padat (block atau pola drapping) dan teknik konstruksi datar (flat pattern drafting). Ada beberapa macam pola dasar yang diberi nama berdasarkan nama penemunya diantaranya Meyneke, Cuppen Geurs, Dressmaking, Danckaerts, Soen, Sonny dimana setiap pola dasar tersebut memiliki masing-masing ciri khas tersendiri.

Selain beberapa macam pola dasar tersebut, adapula pola yang biasa disebut dengan pola dasar sistem praktis, dimana teknik pembuatan pada setiap tempat juga berbeda karena pola dasar praktis biasanya dibuat berdasarkan dari kebiasaan atau modifikasi dari pembuat pola tersebut yang kemudian dipatenkan karena dianggap pola dasar tersebut lebih mudah dibandingkan dengan pola dasar lainnya. 
Kualitas pola pakaian aka
ditentukan oleh beberapa ha
diantaranya adalah: (1). Ketepatan dalam
mengambil ukuran tubuh,
kemampuan dalam menentukan kebenaran garis-garis pola, seperti garis lingkar kerung lengan, garis lekuk leher, bahu, sisi badan, sisi rok, bentuk lengan, kerah dan lain sebagainya, (3) Ketepatan memilih kertas untuk pola, seperti kertas dorslag, kertas karton manila atau kertas koran, (4) kemampuan dan ketelitian memberi tanda dan keterangan setiap bagian-bagian pola, misalnya tanda pola bagian muka dan belakang, tanda arah benang/serat kain, dan lain sebagainya, (5) kemampuan dan ketelitian dalam menyimpan dan mengarsipkan pola. Pola dasar busana merupakan suatu sistem atau cara dalam membuat busana yang masih baku karena belum dirubah sesuai dengan model. Pola busana harus digambar dengan benar berdasarkan ukuran badan seseorang yang diukur secara cermat, agar hasil jadi busana nantinya sesuai dengan bentuk tubuh sipemakai. Begitu pula sebaliknya, jika ukuran yang diambil tidak tepat, menggambar pola juga tidak benar, maka hasil yang didapatkan akan sesuai dengan ukuran seseorang.

\section{Pola Dasar Sistem Sonny}

Menurut Muliawan (1990:2), pattern atau pola dalam bidang jahit menjahit adalah potongan kain atau kertas yang dipakai sebagai contoh untuk membuat baju, ketika bahan akan digunting. Selanjutnya Tamimi (1982) dalam Ernawati, dkk (2008:245) mengemukakan pola ciplakan bentuk badan yang biasa dibuat dari kertas, yang nanti dipakai sebagai contoh untuk menggunting pakaian seseorang, ciplakan bentuk badan ini disebut pola dasar. Berdasarkan beberapa definisi tentang pola, maka dapat disimpulkan bahwa membuat pola merupakan kegiatan membuat ciplakan bentuk badan sesuai dengan ukuran tubuh pemakai yang kemudian dipakai sebagai contoh membuat pakaian.

Pola dasar busana merupakan suatu sistem atau cara dalam membuat busana yang masih baku karena belum dirubah sesuai dengan model. Pola busana harus digambar dengan benar berdasarkan ukuran badan seseorang yang diukur secara cermat, agar hasil jadi busana nantinya sesuai dengan bentuk tubuh sipemakai. Begitu pula sebaliknya, jika ukuran yang diambil tidak tepat, menggambar pola juga tidak benar, maka hasil yang didapatkan akan sesuai dengan ukuran seseorang.Ada beberapa macam pola dasar yang diberi nama berdasarkan nama penemunya diantaranya Meyneke, Cuppen Geurs, Dressmaking, Danckaerts, Soen, Sonny dimana setiap pola dasar tersebut memiliki masing-masing ciri khas tersendiri.

Pola sistem Sonny merupakan pola dasar yang dikembangkan oleh $\mathrm{Hj}$. Sonny Nusi yang kemudian digunakan sebagai dasar dalam pembuatan jas wanita.

Ukuran-ukuran yang diperlukan untuk membuat pola dasar meliputi lingkar badan, lingkar pinggang, lebar muka, panjang muka, tinggi payudara, jarak payudara, lebar bahu, lebar punggung, panjang punggung, lingkar panggul, panjang lengan dan lingkar lengan. Berikut adalah gambar pola dasar badan bagian muka dan belakang serta pola lengan dengan menggunakan sistem Sonny. 


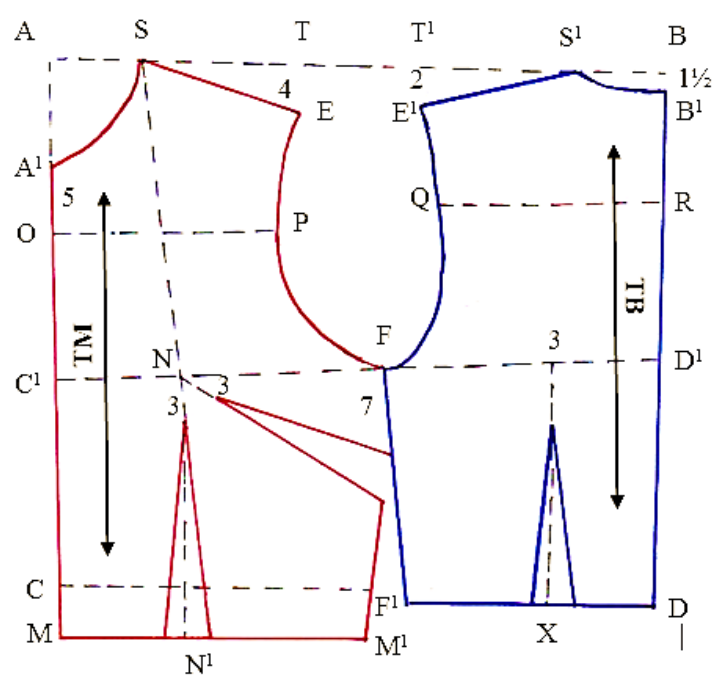

Gambar 1. Pola Dasar Badan Bagian Muka dan Belakang (Sonny)

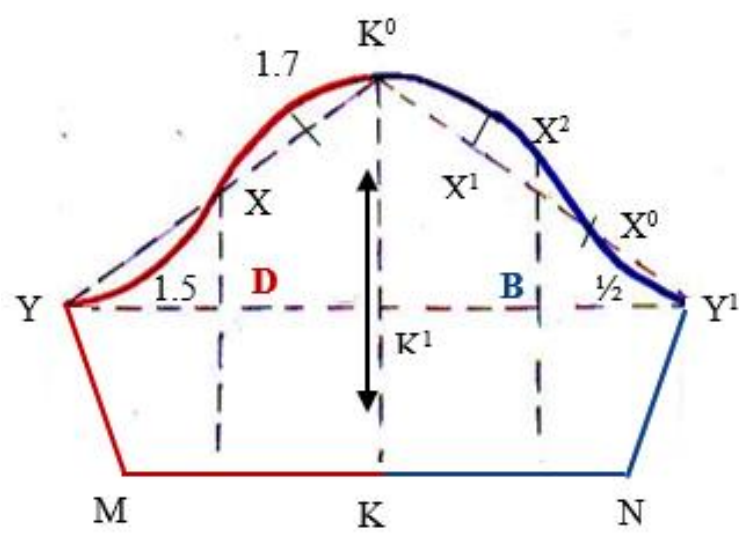

Gambar 2. Pola Dasar Lengan (Sonny)

\section{Pola Dasar Sistem Praktis}

Pola sistem praktis merupakan suatu metode atau cara membuat pola dasar dengan menggunakan teknik atau cara yang cepat dan praktis (Permana: 2012). Dikatakan cepat dan praktis karena hanya menggunakan beberapa macam ukuran saja. Pola dasar praktis yang biasa digunakan dalam pembuatan busana di Jurusan PKK FT UNM yaitu pola dasar yang telah dimodifikasi dari penggabungan beberapa pola dasar yang telah ada. Menurut Nurdiah (1986:35), pola dasar praktis sesuai untuk bentuk badan yang mempunyai buah dada kecil (langsing). Pola dasar praktis ini lebih sering digunakan dalam pembuatan berbagai macam busana karena pembuatannya yang lebih mudah dan mempercepat mahasiswa dalam pembuatan pola. Ukuran-ukuran yang diperlukan untuk membuat pola dasar sistem praktis meliputi lingkar badan, lingkar pinggang, lingkar panggul, tinggi panggul, panjang muka, lebar muka, tinggi dada, panjang bahu, panjang punggung, lebar punggung, lingkar leher, lingkar kerung lengan dan panjang lengan. Berikut adalah gambar pola dasar badan bagian muka dan belakang serta pola dasar lengan dengan menggunakan sistem praktis.
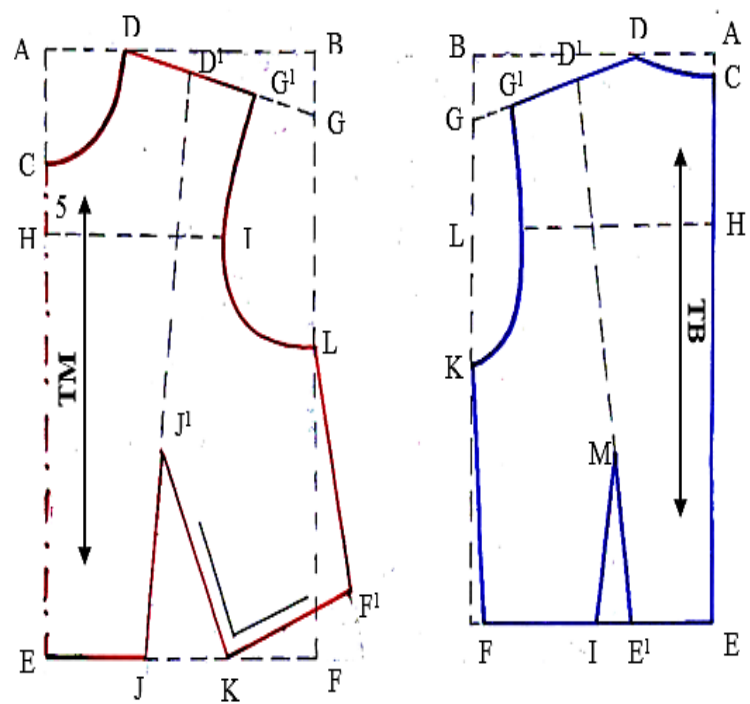

Gambar 3. Pola Dasar Badan Bagian Muka dan Belakang (Praktis)

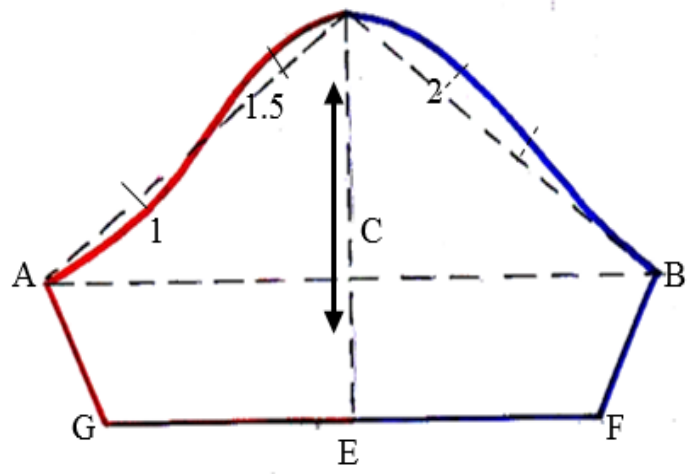

Gambar 4. Pola Dasar Lengan (Praktis) 


\section{METODE}

Penelitian menggunakan pendekatan kuantitatif yang terdiri dari tiga tahapan. Tahapan pertama yaitu pembuatan pola jas wanita menggunakan sistem Sonny dan sistem praktis. Tahapan kedua yaitu melakukan proses pembuatan uji coba produk jas wanita. Selanjutnya adalah tahapan ketiga yang merupakan proses penilaian hasil produk pembuatan jas wanita berdasarkan fitting factor.

Objek dalam penelitian ini adalah produk jas wanita yang telah dibuat menggunakan pola dasar busana konstruksi sistem Sonny dan sistem Praktis yang diuji cobakan pada tubuh model /wanita dewasa dengan ukuran tubuh kurus dan gemuk.

Pengumpulan data dilakukan dengan menggunakan teknik observasi. Instrumen penelitian yang digunakan berupa lembar observasi / pengamatan untuk menilai hasil akhir produk jas wanita yang dilakukan oleh tiga panelis ahli dibidang busana khususnya pembuatan jas pada matakuliah Tailoring, peragawati dan mahasiswa.

Penilaian fitting factor dilakukan dengan mengamati empat belas titik pas pada jas, diantaranya terletak pada kedudukan lingkar badan, lingkap pinggang, lingkar panggul, lebar punggung, panjang punggung, lebar muka, panjang muka, kedudukan kerah, garis hias princess, posisi saku, letak garis bahu, panjang lengan, lingkar kerung lengan dan garis sisi. Hasil pengukuran atas tiap titik pas diberi nilai $1-3$, dengan rincian bila pengepasan (a) tepat, nilai 3, (b) kurang tepat, nilai 2, dan (c) tidak tepat diberi nilai 1.

Data yang diperoleh dari hasil penelitian, kemudian dianalisis dengan menggunakan teknik analisis statistik deskriptif dan analisis statistik inferensial. Analisis statistik deskriptif digunakan untuk mendeskripsikan atau memberi gambaran dari data yang telah terkumpul dalam hal ini terkait dengan hasil penilaian fitting factor pembuatan jas wanita. Setelah itu, data kemudian dianalisis dengan menggunakan rumus persentase.

Selanjutnya, dilakukan teknik analisis statistik inferensial digunakan untuk menguji hipotesis yang diajukan. Namun terlebih dahulu dilakukan uji normalitas dan uji homogenitas untuk memenuhi dua asumsi dasar yaitu data harus berdistribusi normal dan homogen. Setelah itu data dianalisis menggunakan uji t ( $t$-test). Perhitungan uji t digunakan untuk mengukur perbedaan dua atau beberapa mean antar kelompok. Oleh karena itu, untuk mengetahui ada atau tidaknya perbedaan fitting factor jas wanita antara yang menggunakan pola sistem Sonny dengan sistem Praktis maka dilakukan analisis menggunakan independent $t$ test. Perhitungan dilakukan dengan menggunakan bantuan SPSS 20 for windows dengan menggunakan taraf signifikansi 0,05 $(5 \%)$.

\section{HASIL DAN PEMBAHASAN}

Berdasarkan hasil penilaian titik fitting factor, diketahui frekuensi ratarata ketepatan jas wanita bentuk tubuh kurus menggunakan pola Sonny termasuk kategori tepat sebanyak $76 \%$, kategori kurang tepat sebanyak 22\% dan tidak tepat sebanyak 2\%. Dengan demikian, secara umum dapat dinyatakan bahwa fitting factor pola Sonny pada bentuk tubuh kurus berada pada kategori tepat. 


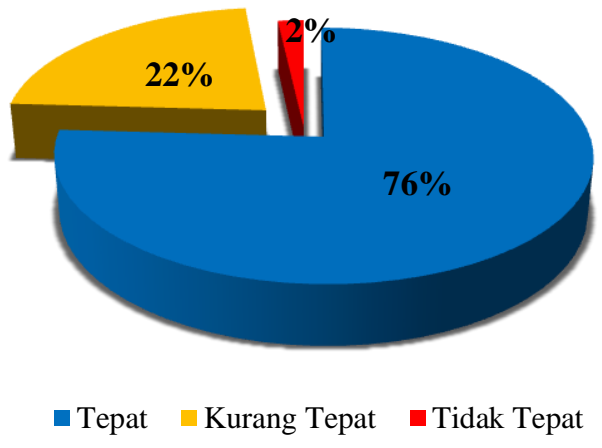

Gambar 5. Diagram Nilai Fitting Factor Pola Sonny pada Bentuk Tubuh Kurus

Berdasarkan hasil penilaian titik pas/fitting factor, diketahui frekuensi rata-rata ketepatan jas wanita bentuk tubuh gemuk menggunakan pola Sonny termasuk kategori tepat sebanyak 68\%, kategori kurang tepat sebanyak 30\% dan tidak tepat sebanyak 2\%. Dengan demikian, secara umum dapat dinyatakan bahwa fitting factor pola Sonny pada bentuk tubuh gemuk berada pada kategori tepat.

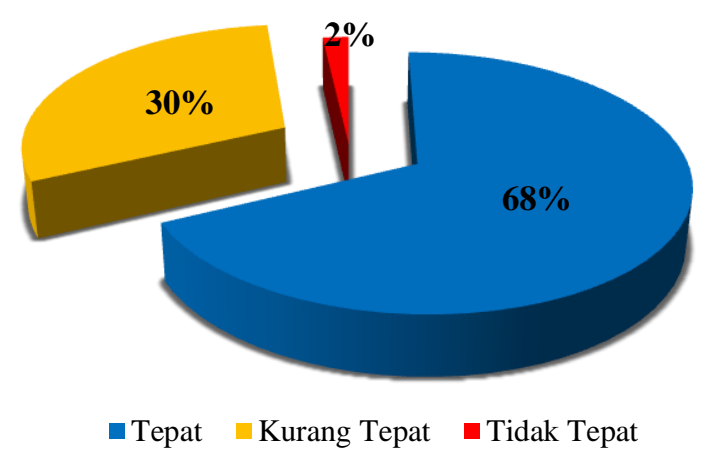

Gambar 6. Diagram Nilai Fitting Factor Pola Sonny pada Bentuk Tubuh Gemuk

Berdasarkan hasil penilaian titik pas/fitting factor, diketahui frekuensi rata-rata ketepatan jas wanita bentuk tubuh kurus menggunakan pola Praktis termasuk kategori tepat sebanyak $61 \%$, kategori kurang tepat sebanyak $27 \%$ dan tidak tepat sebanyak $12 \%$. dengan demikian, secara umum dapat dinyatakan bahwa fitting factor pola Praktis pada bentuk tubuh kurus berada pada kategori tepat.

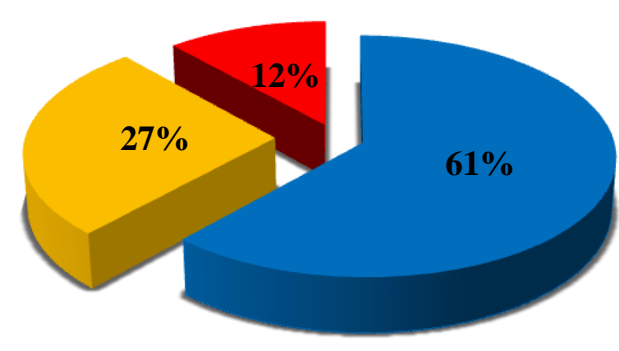

- Tepat $\quad$ Kurang Tepat $\square$ Tidak Tepat

Gambar 7. Diagram Nilai Fitting Factor Pola Dasar Praktis pada Bentuk Tubuh Kurus

Berdasarkan hasil penilaian titik pas/fitting factor, diketahui frekuensi rata-rata ketepatan jas wanita bentuk tubuh gemuk menggunakan pola dasar Praktis termasuk kategori tepat sebanyak $61 \%$, kategori kurang tepat sebanyak $24 \%$ dan tidak tepat sebanyak $15 \%$. Dengan demikian, secara umum dapat dinyatakan bahwa fitting factor pola Praktis pada bentuk tubuh kurus berada pada kategori tepat.

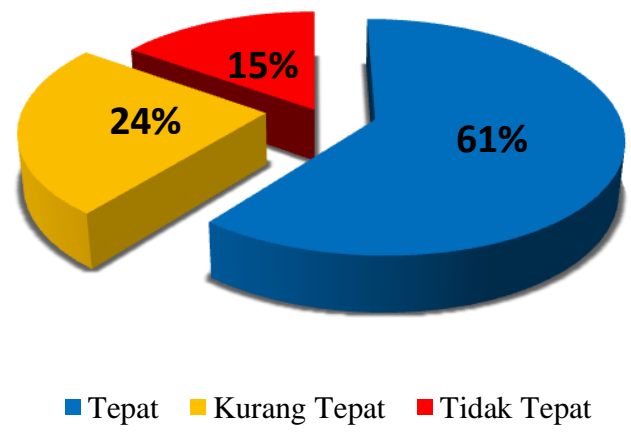

Gambar 8. Diagram Nilai Fitting Factor Pola Dasar Praktis pada Bentuk Tubuh Gemuk 
Berdasarkan hasil analisis yang dilakukan berdasarkan jenis pola pada pembuatan jas wanita dengan bentuk tubuh kurus, diperoleh bahwa pola dasar Sonny memiliki tingkat kenyamanan yang lebih tinggi. Hal tersebut terlihat dari hasil pengamatan yang dilakukan oleh delapan orang panelis yang terdiri atas dosen, peragawati dan mahasiswa.

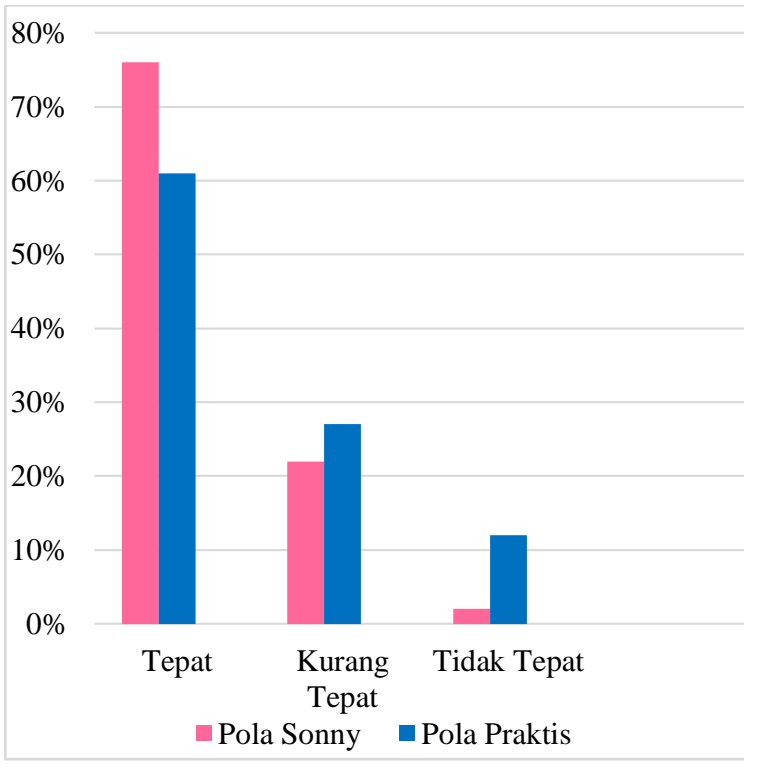

Gambar 9. Diagram Persentase Nilai

Fitting Factor Pola Sonny dan Pola

Praktis pada Jas Wanita dengan bentuk tubuh kurus

Berdasarkan hasil analisis yang dilakukan berdasarkan jenis pola pada pembuatan jas wanita dengan bentuk tubuh kurus, diperoleh bahwa pola dasar Praktis memiliki tingkat kenyamanan yang lebih tinggi. Hal tersebut terlihat dari hasil pengamatan yang dilakukan oleh delapan orang panelis yang terdiri atas dosen, peragawati dan mahasiswa.

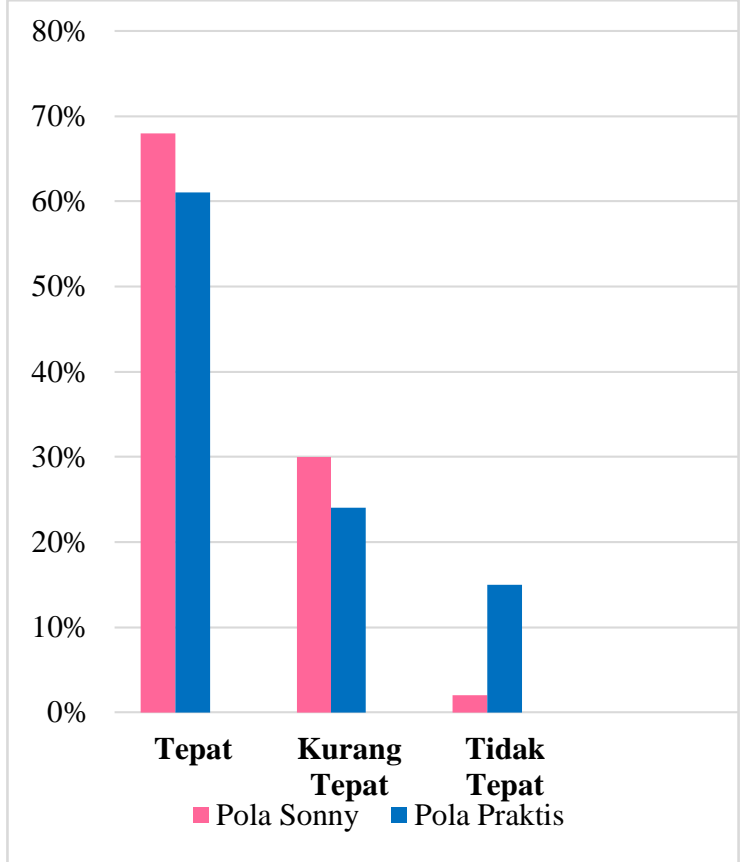

Gambar 10. Persentase Nilai Fitting Factor Pola Sonny dan Pola Praktis pada Jas Wanita dengan Bentuk Tubuh Gemuk

Berdasarkan gambar 11, dapat dilihat bahwa pola Sonny memiliki tingkat ketepatan dalam pembuatan pola jas wanita dibandingkan dengan pola praktis. Hal tersebut terbukti dari persentase beberapa titik pengukuran. Pada pola sistem Sonny memiliki satu titik yang termasuk kategori tidak tepat yaitu pada garis sisi. Sedangkan pada pola sistem praktis memiliki lima titik yang termasuk kategori tidak tepat diantaranya pada lingkar pinggang, lingkar panggul, posisi kerah dan saku, dan panjang lengan. 


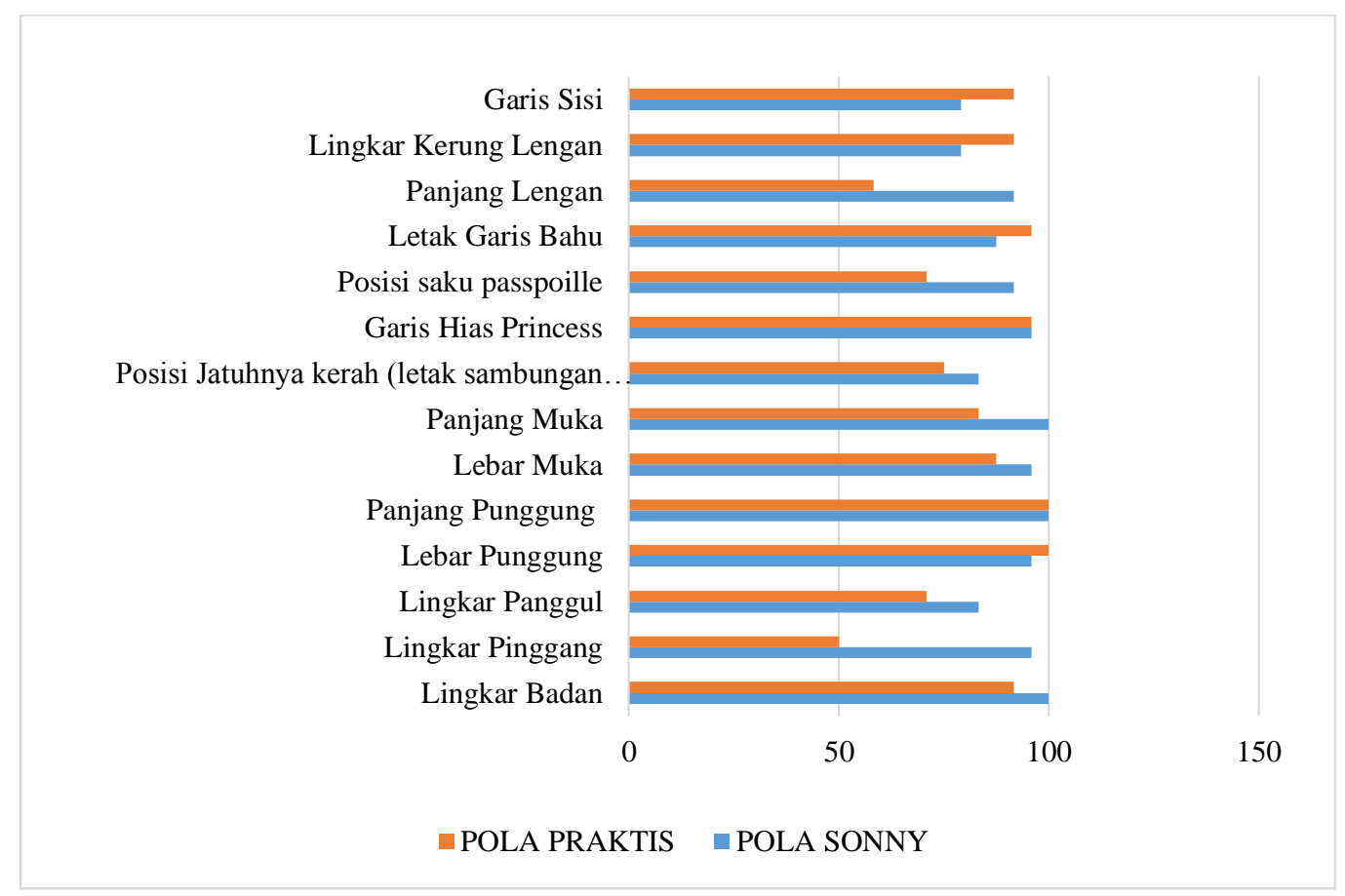

Gambar 11. Diagram Nilai Fitting Factor Bentuk Tubuh Kurus

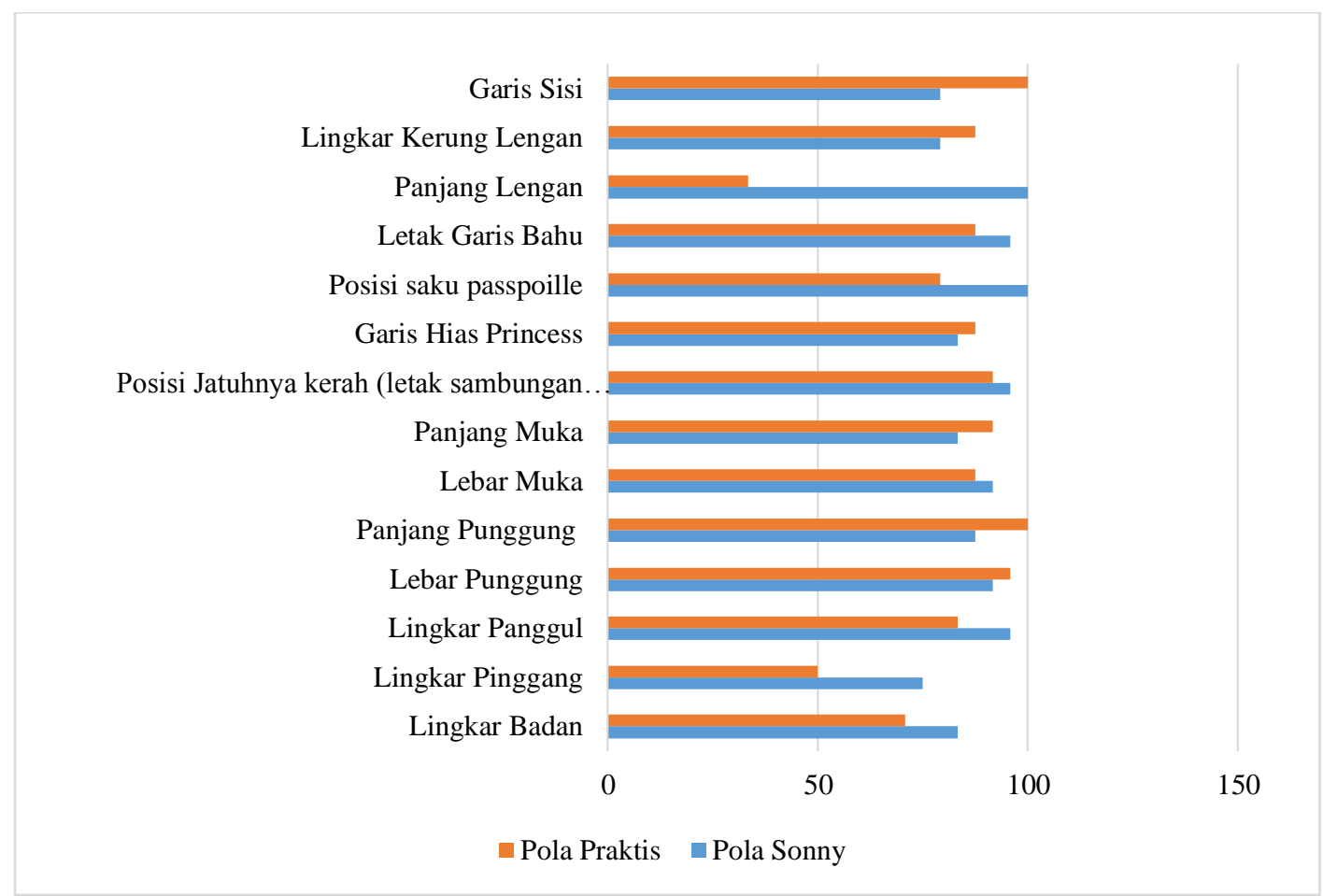

Gambar 12. Diagram Nilai Fitting Factor Bentuk Tubuh Gemuk

Berdasarkan gambar 12, dapat dilihat bahwa pola Sonny memiliki tingkat ketepatan dalam pembuatan pola jas wanita dibandingkan dengan pola praktis. Hal tersebut terbukti dari persentase beberapa titik pengukuran.
Pada pola sistem Sonny memiliki dua titik yang termasuk kategori tidak tepat yaitu pada lingkar badan dan lingkar pinggang. Sedangkan pada pola sistem praktis memiliki enam titik yang termasuk kategori tidak tepat 
diantaranya pada lingkar badan, lingkar pinggang, posisi letak kerah, garis hias princess, panjang lengan dan lingkar kerung lengan.

Selanjutnya berdasarkan uji asumsi klasik yang dilakukan, diketahui bahwa data penelitian berdistribusi normal dan homogen. Selanjutnya, dilakukan pengujian hipotesis dengan hasil sebagai berikut:

Tabel 1. Ringkasan Uji Signifikansi

\begin{tabular}{ccccc}
\hline Hipotesis & Nilai & Sig & Kondisi & Keterangan \\
\cline { 2 - 4 } & & & Sig $<0,05$ & Signifikan \\
\hline $\begin{array}{c}\text { Nilai Fitting Factor Pola } \\
\text { Sonny } \neq \text { Pola Praktis (Bentuk } \\
\text { Tubuh Kurus) }\end{array}$ & $\mathrm{t}=2.812$ & 0.014 & & \\
$\begin{array}{c}\text { Nilai Fitting Factor Pola } \\
\text { Sonny } \neq \text { Pola Praktis (Bentuk } \\
\text { Tubuh Gemuk) }\end{array}$ & $\mathrm{t}=2.891$ & $0, .012$ & Sig $<0,05$ & Signifikan \\
\hline
\end{tabular}

Berdasarkan pengujian hipotesis yang dilakukan pada produk pembuatan jas wanita pada bentuk tubuh kurus diperoleh bahwa $\mathrm{t}_{\text {hitung }}=2.812>\mathrm{t}_{\text {tabel }}=$ 2.145, dengan nilai Sig.variabel 0,05 > 0,014, maka Ha diterima artinya signifikan. Terbukti bahwa terdapat perbedaan yang signifikan fitting factor hasil jadi jas wanita antara yang menggunakan pola sistem Sonny dengan sistem pola sistem praktis.

Sedangkan hasil uji hipotesis pada produk jas wanita pada bentuk tubuh gemuk diperoleh bahwa $\mathrm{t}_{\text {hitung }}=2.891>$ $\mathrm{t}_{\text {tabel }}=2.145$, dengan nilai Sig.variabel $0,05>0,012$, maka Ha diterima artinya signifikan. Terbukti bahwa terdapat perbedaan yang signifikan fitting factor hasil jadi jas wanita antara yang menggunakan pola sistem Sonny dengan sistem pola sistem praktis.

\section{SIMPULAN}

Berdasarkan hasil analisis maka dapat disimpulkan bahwa terdapat perbedaan fitting factor hasil jadi jas wanita antara yang menggunakan pola dasar Sonny dengan pola dasar praktis baik yang bertubuh kurus maupun gemuk.
Selain itu, hasil analisis juga menunjukkan pola sistem Sonny memiliki tingkat ketepatan titik pas dalam pembuatan jas wanita yang lebih tinggi dari pada pola sistem praktis.

Oleh karena itu, untuk mahasiswa pada matakuliah Tailoring dapat menggunakan pola dasar Sonny dan pola dasar praktis dalam pembuatan jas wanit. Namun perlu diperhatikan adalah dalam penggunaan pola dasar harus mempertimbangkan bentuk tubuh dari model yang akan dibuatkan jas wanita.

Penelitian ini perlu diperdalam dengan menggunakan sampel yang lebih banyak/luas dengan lebih memperhatikan ketepatan dari teknik pengambilan ukuran utuh model. Selain itu, penelitian ini juga perlu dikembangkan lebih lanjut untuk menciptakan maupun memodifikasi pola dasar yang tepat sehingga dapat diguanakan dalam pembuatan jas wanita dengan hasil yang lebih memuaskan baik ditinjau dari tingkat kenyamanan maupun dari kedudukan fitting factor busana tersebut. 


\section{DAFTAR PUSTAKA}

Eka, Wahyuni. 2011. Busana Wanita. Yogyakarta: PT. Intan Sejati Klaten

Ernawati; Izwerni \& Nelmira, Weni. 2008. Tata Busana untuk SMK (Jilid 2). Jakarta: Direktorat Pembinaan Sekolah Menengah Kejuruan, Direktorat Jenderal Manajemen Pendidikan Dasar dan Menengah, Departemen Pendidikan Nasional.

Joseph, Helen-Armstrong. 2010. Patternmaking for Fashion Design (Fifth Edition). New Jersey: Prentice Hall, Upper Saddle River.

Lestari, Dyan Sukma Sekti Lestari. 2012. Analisis Fitting Factor Pada Vuring Blazer Sistem Soekarno. Skripsi. Universitas Negeri Malang.

Maeliah. Mally. 2010. Modul Perkuliahan Busana Tailoring (BU 473). Bandung: Universitas Pendidikan Indonesia.

Muliawan, Porrie. 1990. Konstruksi Pola Busana Wanita. Jakarta: PT. BPK Gunung Mulia.

Nurdiah Maming. 1986. Modul Busana Wanita. Makassar: Jurusan PKK Universitas Negeri Makassar.

Nusi, Sonny \& Zaman, Alim. 2002. Jas Wanita: Sejarah-Gaya \& Cara Praktis Pembuatan Jas Wanita. Jakarta: Meutia Cipta Sarana.

Partino, H.R dan Idrus, H.M. 2010. Statistik Inferensial. Yogyakarta: Safiria Insania Press.

Permana, Maya. 2012. Analisis Tingkat Kenyamanan Pembuatan Kebaya Dengan Pola Praktis Pada Ukuran
Tubuh M (medium). Skripsi. Universitas Negeri Malang.

Prahastuti, Endang. 2012. Aplikasi Pola Dasar Pakaian Sistem Charmant dan Dankertz pada berbagai bentuk Tubuh Wanita. Jurnal. Jurnal TIBBS (Teknologi Industri Boga dan Busana), Vol. 3 No. 1 Maret 2012: 23-29. http://download.portalgaruda.org/art icle.php?article $=98734 \&$ val $=420$, Diakses 15 Mei 2016.

Rachmania, dkk. 2012. Analisis Tingkat Kenyamanan Gaun Berukuran L yang Dibuat menggunakan Pola Meyneke dan Pola So-en. Jurnal TIBBS (Teknologi Industri Boga dan Busana), Vol. 1 No. 1 Maret 2012: 37-43.

http://download.portalgaruda.org/art icle.php?article $=98735 \& \mathrm{val}=420$. Diakses 15 Mei 2016.

Riduwan dan Sunarto. 2010. Pengantar Statistika. Bandung: Alfabeta.

Safitri, Vina. 2015. Studi Tentang Titik Pas (Fitting Factor) Jas Pria Ukuran S, M, L Menggunakan "Pola Diatas Bahan". Skripsi. Universitas Negeri Malang.

Sugiyono. 2007. Metode Penelitian Pendidikan Pendekatan Kuantitatif, Kualitatif, dan $R \& D$. Bandung: Alfabeta.

Sulistio, Hartatiati. Rancang Busana, Terampil Membentuk Pribadi Mempesona. Semarang: UPT. Unnes Press.

Wiyono, Gendro. 2011. Merancang Penelitian Bisnis dengan Alat Analisis SPSS 17.0 \& SmartPLS 2.0. Yogyakarta: STIM YKPN Yogyakarta. 